\title{
Sodium chloride promotes tissue inflammation via osmotic stimuli in subtotal-nephrectomized mice
}

\author{
Fumiko Sakata', Yasuhiko Ito ${ }^{1}$, Masashi Mizuno ${ }^{1}$, Akiho Sawai ${ }^{1}$, Yasuhiro Suzuki ${ }^{1}$, Takako Tomita', Mitsuhiro Tawada ${ }^{1}$, \\ Akio Tanaka², Akiyoshi Hirayama ${ }^{3}$, Akihiro Sagara ${ }^{4}$, Takashi Wada ${ }^{4}$, Shoichi Maruyama' ${ }^{1}$, Tomoyoshi Soga ${ }^{3}$, \\ Seiichi Matsuo', Enyu Imai ${ }^{1,5,6}$ and Yoshifumi Takei ${ }^{7}$
}

Chronic inflammation, which is often associated with high all-cause and cardiovascular mortality, is prevalent in patients with renal failure; however, the precise mechanisms remain unclear. High-salt intake was reported to induce lymphangiogenesis and autoimmune diseases via osmotic stimuli with accumulation of sodium or chloride. In addition, sodium was recently reported to be stored in the extremities of dialysis patients. We studied the effects and mechanisms of high salt loading on tissue and systemic inflammation in subtotal-nephrectomized mice $(5 / 6 \mathrm{Nx})$ and in cultured cells. Macrophage infiltration in the peritoneal wall $(P<0.001)$, heart $(P<0.05)$ and para-aortic tissues $(P<0.001)$ was significantly higher in $5 / 6 \mathrm{Nx}$ with salt loading $(5 / 6 \mathrm{Nx} / \mathrm{NaCl})$ than in $5 / 6 \mathrm{Nx}$ without salt loading $(5 / 6 \mathrm{Nx} / \mathrm{Water})$; however, there were no significant differences in blood pressure and renal function between the groups. Tissue interleukin- 6 , monocyte chemotactic protein-1 (MCP-1), serum- and glucocorticoid-inducible kinase 1 (Sgk1) and tonicity-responsive enhancer binding protein (TonEBP) mRNA were significantly elevated in the peritoneal wall and heart with $5 / 6 \mathrm{Nx} / \mathrm{NaCl}$ when compared with 5/6Nx/Water. Sodium was stored in the abdominal wall, exerting high-osmotic conditions. Reversal of salt loading reduced macrophage infiltration associated with decreased TonEBP in 5/6Nx/NaCl. Macrophage infiltration associated with fibrosis induced by salt loading was decreased in the $5 / 6 \mathrm{Nx} / \mathrm{NaCl} / \mathrm{CC}$ chemokine receptor 2 (CCR2, receptor of MCP-1)-deficient mice when compared with $5 / 6 \mathrm{Nx} / \mathrm{NaCl} /$ Wild mice, suggesting that CCR2 is required for macrophage infiltration in $5 / 6 \mathrm{Nx}$ with $\mathrm{NaCl}$ loading. In cultured mesothelial cells and cardiomyocytes, culture media with high $\mathrm{NaCl}$ concentration induced MCP-1, Sgk1 and TonEBP mRNA, all of which were suppressed by TonEBP siRNA, indicating that both MCP-1 and Sgk1 are downstream of TonEBP. Our study indicates that high NaCl intake induces MCP-1 expression leading to macrophage infiltration via the TonEBP-MCP-1 pathway in $5 / 6 \mathrm{Nx} / \mathrm{NaCl}$ mice, and that TonEBP has a central role in inflammation in patients with renal failure taking high salt.

Laboratory Investigation (2017) 97, 432-446; doi:10.1038/labinvest.2017.4; published online 6 February 2017

Patients with renal failure have a higher risk of death, particularly from cardiovascular diseases, as compared with the general population. ${ }^{1}$ Protein-energy wasting and atherosclerosis in association with inflammation are common problems in predicting morbidity and mortality in patients with end-stage renal disease. ${ }^{1,2}$ Elevation of serum C-reactive protein, interleukin-6 (IL-6) and other inflammatory markers is often observed and may be a predictor of survival in patients with chronic kidney disease (CKD) and on dialysis. ${ }^{3-5}$ We reported that a combination of these variables could more accurately predict mortality. ${ }^{6,7}$ We recently demonstrated that macrophage infiltration in the peritoneal membrane, which is predominant in uremic patients and is an important factor in determining baseline peritoneal permeability, is a predictor of technical failure and survival in peritoneal dialysis patients. ${ }^{8}$ This was demonstrated by analysis of pre-dialysis peritoneal biopsy samples obtained at the time of peritoneal dialysis catheter insertion. ${ }^{8}$ In these respects, the pathogenesis of inflammation in CKD patients is important; however, the precise mechanisms remain unclear.

Recently, there have been reports suggesting that high-salt intake induces progression in immunological activation and

\footnotetext{
${ }^{1}$ Department of Nephrology and Renal Replacement Therapy, Nagoya University Graduate School of Medicine, Nagoya, Japan; ${ }^{2}$ Department of Pharmacy, Daido General Hospital, Nagoya, Japan; ${ }^{3}$ Institute for Advanced Biosciences, Keio University, Tsuruoka, Japan; ${ }^{4}$ Department of Nephrology, Kanazawa University Graduate School of Medicine, Kanazawa, Japan; Internal Medicine of Nakayamadera Imai Clinic, Takarazuka, Japan; ${ }^{6}$ Department of Nephrology, Fujita Health University, Toyoake, Japan and ${ }^{7}$ Department of Biochemistry, Nagoya University Graduate School of Medicine, Nagoya, Japan

Correspondence: Professor Y Ito, MD, Department of Nephrology and Renal Replacement Therapy, Nagoya University Graduate School of Medicine, 65 Tsurumai-cho, Showa-ku, Nagoya 466-8550, Japan.
}

E-mail: yasuito@med.nagoya-u.ac.jp

Received 24 August 2016; revised 16 December 2016; accepted 27 December 2016 
autoimmune diseases. ${ }^{9-11}$ Several studies have reported that after high-salt intake, sodium induces lymphangiogenesis via osmotic stimuli through activation of the tonicity-responsive enhancer binding protein (TonEBP)/nuclear factor of activated T cells 5 (NFAT5)-vascular endothelial growth factor (VEGF)-C signaling pathway in macrophages, thereby lowering blood pressure. ${ }^{9,11,12}$ High-salt intake also causes peritoneal fibrosis and thickening of the submesothelial layer, and induces epithelial-mesenchymal transition associated with upregulation of inflammatory cytokines in rodents. ${ }^{13}$ In addition, daily sodium intake in CKD patients under regular nephrology care is reported to be higher than recommended, ${ }^{14}$ and patients with renal failure have difficulty achieving sodium balance, thereby resulting in sodium accumulation during high sodium diet intake. ${ }^{15}$

Little is currently known about the potential effects of sodium on target organ damage in uremia. ${ }^{16}$ In this study, we investigated the roles of high sodium loading on tissue and systemic inflammatory changes in subtotal-nephrectomized mice and cultured cells.

\section{MATERIALS AND METHODS Animal Model}

All of the animal studies were carried out in accordance with the Animal Experimentation Guidelines of Nagoya University Graduate School of Medicine (Nagoya, Japan) and were approved by the Animal Experimentation Committee of Nagoya University (approval \# 25378). Eight- to 10-week-old male 129SvJJmsSlc mice (Japan SLC, Hamamatsu, Japan) weighing $20-25 \mathrm{~g}$ were used throughout the study. Animals were maintained under conventional laboratory conditions and were given free access to food and water. Mice underwent subtotal nephrectomy $(5 / 6 \mathrm{Nx})$ or sham surgery (Sham), and drinking water was either tap water (Water) or $1 \% \mathrm{NaCl}$ water $(\mathrm{NaCl})$ (Supplementary Figure 1). Renal ablation was performed as described previously. ${ }^{17}$ Briefly, mice were anesthetized with diethyl ether (Wako, Osaka, Japan). The flank region was shaved, and animals were placed on a heating pad to maintain a constant body temperature $\left(37^{\circ} \mathrm{C}\right)$. Under anesthesia, a left flank incision was made, and two-thirds of the mass of the left kidney was ablated. Seven days later, mice were anesthetized as above, and the right kidney was removed. After renal ablation, the flank was closed in two layers with 5-0 silk sutures. In control mice, sham surgery was performed. Mice were classified into four groups, including sham-operated mice with water (Sham/Water: $n=6,0$ weeks; $n=6,2$ weeks; $n=6,4$ weeks), sham-operated mice with $1 \%$ $\mathrm{NaCl}$ water (Sham/NaCl: $n=6,2$ weeks; $n=6,4$ weeks), subtotal-nephrectomized mice with water $(5 / 6 \mathrm{Nx} / \mathrm{Water}$ : $n=7,2$ weeks; $n=8,4$ weeks) and subtotal-nephrectomized mice with salt loading $(5 / 6 \mathrm{Nx} / \mathrm{NaCl}: n=6,2$ weeks; $n=6$, 4 weeks) (Supplementary Figure 1a). Blood pressure and body weight were measured every 2 weeks. Blood pressure was measured and assessed as the mean value of eight consecutive measurements using a tail-cuff sphygmomanometer under unstressed conditions (BP-98A; Softron, Tokyo, Japan), as described previously. ${ }^{17}$ Mice were killed on days 14 or 28 under anesthesia with diethyl ether (Wako). Heart, parietal peritoneal samples and aorta including para-aortic tissues were harvested and were processed for routine histology, immunohistochemistry and total RNA isolation.

In a study to reverse $\mathrm{NaCl}$ loading by furosemide, serum creatinine levels, blood pressure, body weight, tissue macrophage infiltration and expression of monocyte chemotactic protein-1 (MCP-1), TonEBP and serum- and glucocorticoidinducible kinase 1 (Sgk1) mRNA were compared between $5 / 6 \mathrm{Nx} / \mathrm{NaCl}$ and $5 / 6 \mathrm{Nx} / \mathrm{NaCl}$ mice with furosemide $(n=5$ each group) (Supplementary Figure 1b). Furosemide (10 mg/ kg; Sanofi-Aventis, Paris, France) was administered subcutaneously once daily for 4 weeks. The doses of furosemide were increased to $20 \mathrm{mg} / \mathrm{kg}$ when body weight increased to $>120 \%$ of the previous day and was reduced to $5 \mathrm{mg} / \mathrm{kg}$ when body weight decreased to $<90 \%$ of the previous day.

In another study, to reverse $\mathrm{NaCl}$ loading, mice underwent subtotal nephrectomy $(5 / 6 \mathrm{Nx})$ or sham surgery (Sham), and drinking water was tap water $(\mathrm{W})$ or $1 \% \mathrm{NaCl}$ water $(\mathrm{Na})$. $5 / 6 \mathrm{Nx} / \mathrm{NaCl} /$ Water mice were then changed from $1 \% \mathrm{NaCl}$ water to water at 4 weeks (Supplementary Figure 1c).

CC chemokine receptor 2 (CCR2)-deficient mice were provided by Drs N Mukaida and T Wada (Kanazawa University, Kanazawa, Japan). ${ }^{18,19}$ Mice were classified into three groups: Sham/Water/Wild mice $(n=6), 5 / 6 \mathrm{Nx} / \mathrm{NaCl} /$ Wild mice $(n=6)$ and $5 / 6 \mathrm{Nx} / \mathrm{NaCl} / \mathrm{CCR} 2-\mathrm{KO}$ mice $(n=6)$ (Supplementary Figure 1d).

\section{Processing of Samples and Analysis}

One part of each tissue sample was fixed with $10 \%$ buffered formalin overnight, routinely processed for light microscopy and embedded in paraffin. Sections $(4 \mu \mathrm{m})$ were cut and stained with hematoxylin and eosin (HE) and Masson'strichrome. A second part was snap frozen in liquid nitrogen. Sections $(4 \mu \mathrm{m})$ were cut with a cryostat and used for IHC. A third part of each tissue sample was immersed in RNAlater (Ambion, Austin, TX, USA) for total RNA isolation. To preserve the integrity and stability of total RNA, all of the steps were performed at $4{ }^{\circ} \mathrm{C}$ under sterile conditions. Immunohistochemical analysis was performed for CD68-, ER-HR3-, CD86-, CD206- (mannose receptor) and CD163positive macrophages, and mRNA expression was examined for CD86, CD206, IL-6, MCP-1, Sgk1, TonEBP, NADPH oxidase (NOX) -2, NOX-4, glutathione reductase (Gsr), glutamate-cysteine ligase catalytic subunit (Gclc) and thioredoxin reductase 1 (Txnrd1). Serum IL-6 concentration was measured by enzyme-linked immunosorbent assay (ELISA).

\section{Histology and Immunohistochemistry}

Immunostaining for ER-HR3 was performed on buffered formalin-fixed tissues and on frozen sections. ${ }^{20,21}$ Immunostaining for MCP-1, TonEBP, CD68, CD86, CD163 and CD206 was performed using $4-\mu \mathrm{m}$ cryostat sections, as 
described previously. ${ }^{9,22,23}$ The antibodies used are listed in Supplementary Table 1.

\section{Morphological Analysis}

CD68-, ER-HR3-, CD86-, CD206- and CD163-positive macrophages were identified and counted using a Zeiss Z1 image microscope and Axiovision Windows software version 4.4 (Carl Zeiss, Oberkochen, Germany), as described previously. ${ }^{9,22,23}$ Macrophages were counted in at least 10 random $750 \times 500-\mu \mathrm{m}$ areas at $\times 200$ magnification of the peritoneal wall and are expressed in terms of counts per square millimeter $\left(/ \mathrm{mm}^{2}\right)$.

\section{Enzyme-Linked Immunosorbent Assay}

MCP-1 and IL-6 protein levels in cell culture supernatant or in serum were measured using Human CCL2/MCP-1 Immunoassay (R\&D, Minneapolis, MN, USA) and mouse IL-6 immunoassay (R\&D) for IL-6, in accordance with the manufacturer's instructions. Samples were frozen at the time of collection and were stored at $-80^{\circ} \mathrm{C}$. Samples were not subjected to freeze-thaw cycles.

\section{Measurement of Tissue $\mathrm{Na}$ and Water Content}

We performed chemical analysis of electrolytes and water content in the abdominal tissues using the modifications of previously reported methods. ${ }^{9,11}$ We removed and weighed the abdominal wall tissues (wet weight (WW)), then performed desiccation at $90^{\circ} \mathrm{C}$ for $72 \mathrm{~h}$ (dry weight (DW)). Tissue water content was measured by the difference between $(\mathrm{WW})$ and $(\mathrm{DW})$. We further ashed the separated tissues at $600{ }^{\circ} \mathrm{C}$ for $48 \mathrm{~h}$, followed by dissolution in $10 \% \mathrm{HNO}_{3}$. We measured $\mathrm{Na}$ concentration by inductively coupled plasma mass spectrometry (ICP-MS) (Agilent 7700X; Agilent Technology, Santa Clara, CA, USA). We measured Na content in the abdominal tissues at 4 weeks in sham/water mice $(n=5)$, 4 weeks in $5 / 6 \mathrm{Nx} / \mathrm{NaCl}$ mice $(n=5)$ and 8 weeks in $5 / 6 \mathrm{Nx} /$ $\mathrm{NaCl}$ mice $(n=5)$.

\section{Capillary Electrophoresis Time-of-Flight Mass Spectrometry (CE-TOFMS) Analysis}

Serum and tissue concentrations of oxidized and reduced glutathione were measured by CE-TOFMS, as described previously. ${ }^{24,25}$

\section{Cell Culture Study}

A human mesothelial cell line (Met5A) was purchased from the American Type Culture Collection (ATCC, Manassas, VA, USA), and was maintained as reported previously. ${ }^{23,26}$ Cells reached confluence in 3-5 days and were then split two to three times and cultured. Subconfluent Met5A were washed twice with PBS, and the culture medium was replaced with serum-free medium for $24 \mathrm{~h}$ in order to render the cells quiescent. Subsequently, the culture medium was changed to medium with increased osmolality by addition of $\mathrm{NaCl}$. Cells were harvested at 0 (basal condition) and $24 \mathrm{~h}(n=3$ dishes of cells at each time point). Human cardiomyocytes were obtained from PromoCell (Heidelberg, Germany) and were cultured in myocyte growth medium $(\mathrm{Na} 123 \mathrm{mEq} / \mathrm{l}$, $280 \mathrm{mOsm} / \mathrm{l} \mathrm{H}_{2} \mathrm{O}$, PromoCell) according to the manufacturer's protocol. Similar experiments were performed using cardiomyocytes. The effects of medium osmolality on Met5A and cardiomyocytes were examined by MCP-1 protein and mRNA, and TonEBP and Sgk1 mRNA. Cells were incubated in isotonic $\left(\mathrm{Na}^{+} 142.5 \mathrm{mEq} / \mathrm{l}, 305 \mathrm{mOsm} / \mathrm{l} \mathrm{H}_{2} \mathrm{O}\right)$ or hypertonic $\left(\mathrm{Na}^{+} 190 \mathrm{mEq} / \mathrm{l}, 390 \mathrm{mOsm} / \mathrm{l} \mathrm{H}_{2} \mathrm{O}\right)$ medium by adding $\mathrm{NaCl}$ and were harvested at $24 \mathrm{~h}$.

\section{RNA Preparation from Tissues and Cultured Cells, and Quantitative PCR Analysis}

RNA preparation and synthesis of first-strand cDNA were performed as described previously. ${ }^{22,23,26}$ Total RNA (1 $\left.\mu \mathrm{g}\right)$ was then reverse transcribed. Real-time polymerase chain reaction analysis was performed using an Applied Biosystems Prism 7500HT sequence detection system with TaqMan gene expression assays, as described previously. ${ }^{22,23,26}$ The TaqMan Gene Expression Assays (Applied Biosystems) used are listed in Supplementary Table 2. 18S ribosomal RNA was used as an endogenous control. . $2,23,26$

\section{TonEBP Knockdown Using siRNA}

Inhibition studies of TonEBP were performed using siRNA. We purchased TonEBP siRNA (ON-TARGET plus SMART pool siRNA) and negative control siRNA (ON-TARGET plus non-targeting control Pool, catalog \#001810-10, Thermo Fisher Scientific, Waltham, MA, USA). siRNA was transfected using Lipofectamine RNAiMAX Transfection Reagent (Life Technologies, Carlsbad, CA, USA) in accordance with the manufacturer's protocol and as described previously. ${ }^{27}$ Briefly, siRNA and Lipofectamine RNAiMAX were diluted in Opti-MEM and were then mixed and incubated for $20 \mathrm{~min}$. Met5A cells and cardiomyocytes were plated at a density of $1.0 \times 10^{5}$ cells and $1.4 \times 10^{5}$ cells $/ 35-\mathrm{mm}$ tissue culture dish, respectively. Cells were transfected with siRNA-Lipofentamine RNAiMAX complexes in serum-free medium at final siRNA concentrations of 100,10 and $1 \mathrm{nM}$. We also used another transfection method in cardiomyocytes.

\section{Statistical Analyses}

Values are expressed as means \pm s.d. Differences between two groups were analyzed by Student's $t$-test or by Mann-Whitney test. Comparisons among groups were performed by one-way analysis of variance followed by Dunnett's or Kruskal-Wallis multiple comparison tests. Differences were considered to be statistically significant at $P<0.05$. All analyses were performed using SPSS software (SPSS, Chicago, IL, USA). 
a

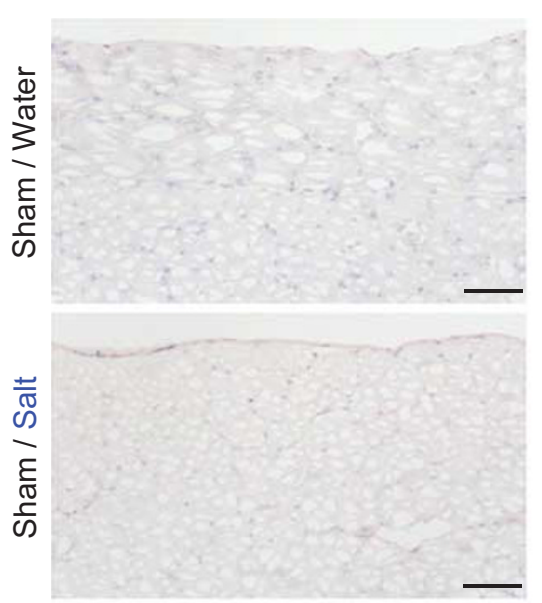

b

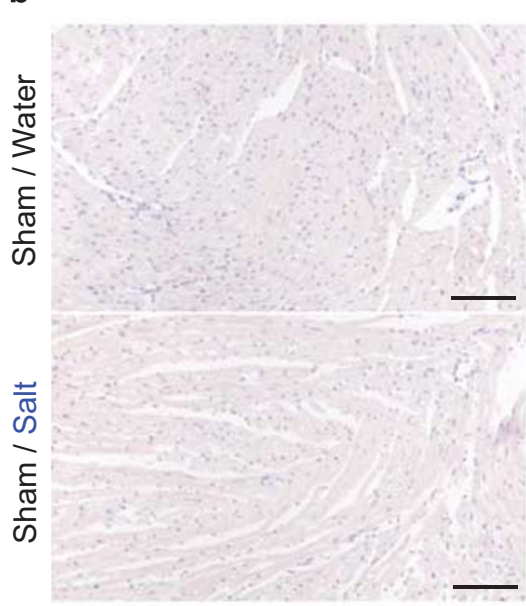

C
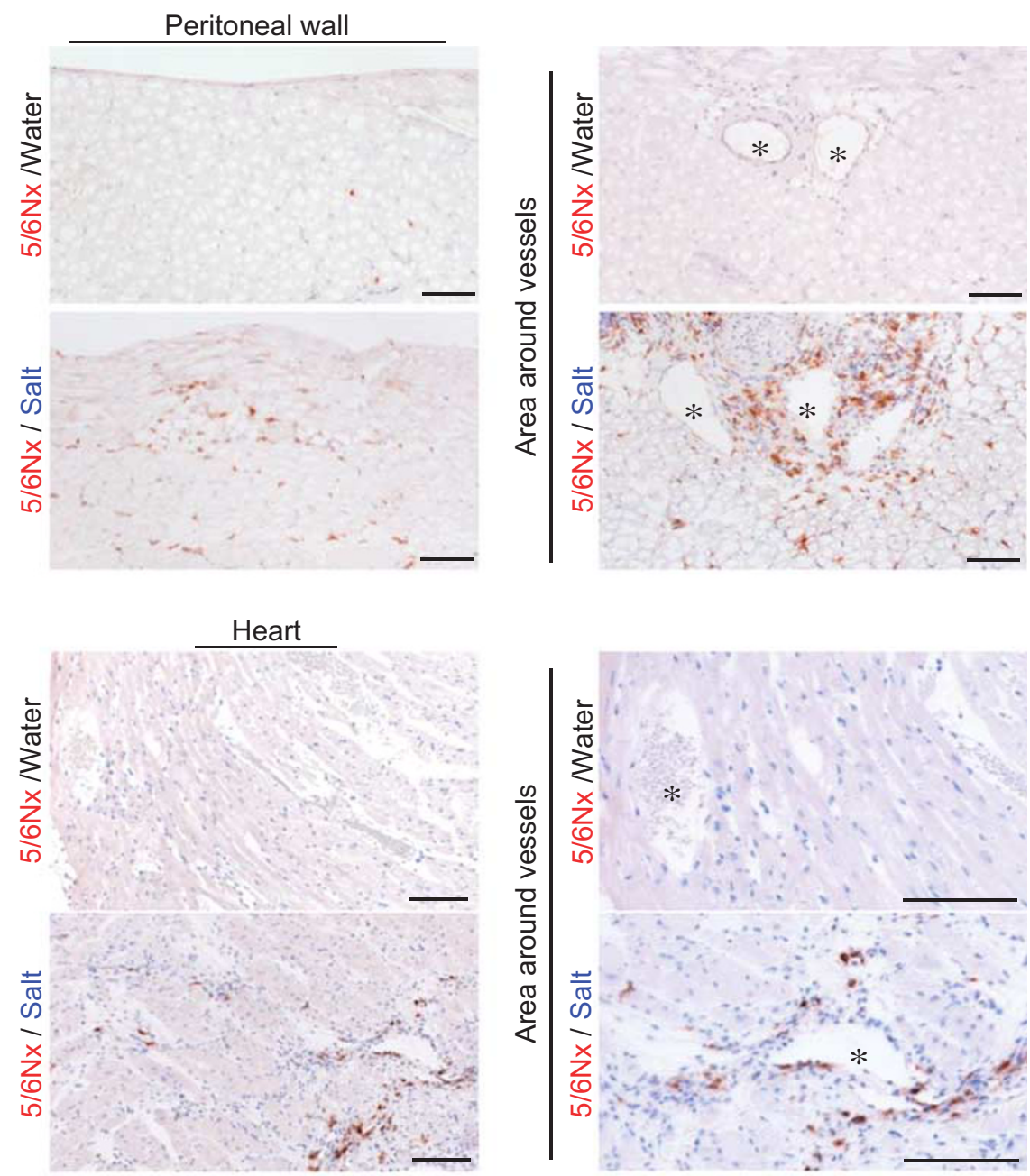

\section{ER-HR3 positive macrophages}
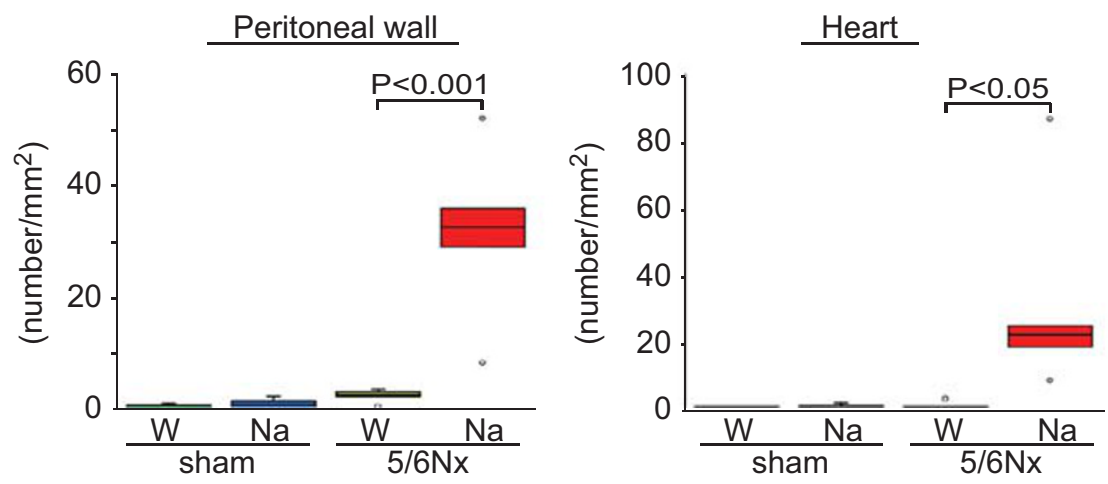

Figure 1 Macrophages are predominant in peritoneal wall and heart in 5/6 nephrectomized mice with $\mathrm{NaCl}$ loading. At 4 weeks, ER-HR3-positive (a, b) macrophages showed significantly higher levels in the peritoneal wall $(P<0.001)$ and heart $(P<0.05)$ of $5 / 6 \mathrm{Nx} / \mathrm{NaCl}$ mice when compared with $5 / 6 \mathrm{Nx} / \mathrm{Water}$ mice. Macrophage infiltration is predominant around the vessels. Macrophages were rarely detectable in sham/water and sham/ $\mathrm{NaCl}$ mice. (a) Peritoneal wall; (b) Heart; *, vessel. (c) Positive cells were counted. Scale bars: $100 \mu \mathrm{m}$. Na, NaCl (with NaCl loading); W, water (without NaCl loading); 5/6Nx, subtotal nephrectomy.

Figure 2 Expression of inflammatory markers at 2 and 4 weeks, as assessed by quantitative RT-PCR. In the peritoneal wall, CD86, CD206 (mannose receptor), IL-6 and MCP-1 mRNA expression, as assessed by real-time PCR, was significantly upregulated in $5 / 6 \mathrm{Nx} / \mathrm{NaCl}$ mice when compared with 5/6Nx/Water mice at 4 weeks (a-d). In the heart, CD206, IL-6 and MCP-1 mRNA expression was significantly higher at 4 weeks in 5/6Nx/NaCl mice than in 5/6Nx/Water mice (e-h). The results of CD163mRNA expression were similar to CD206 (M2 marker) mRNA expression (data not shown). Ctrl, control mice at 0 weeks; $\mathrm{Na}, \mathrm{NaCl}$ (with $\mathrm{NaCl}$ loading); W, water (without $\mathrm{NaCl}$ loading); 5/6Nx, subtotal nephrectomy. 


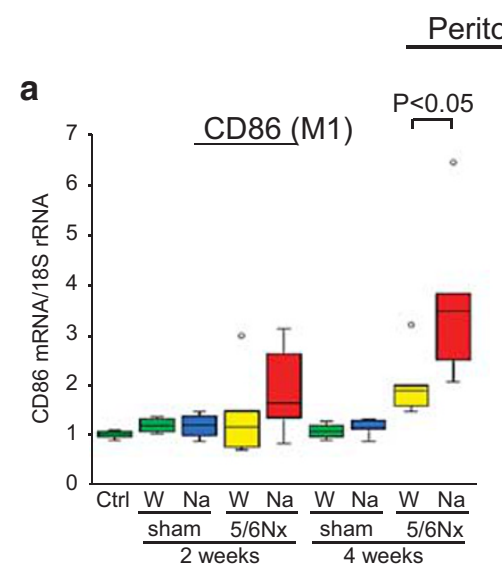

Peritoneal wall
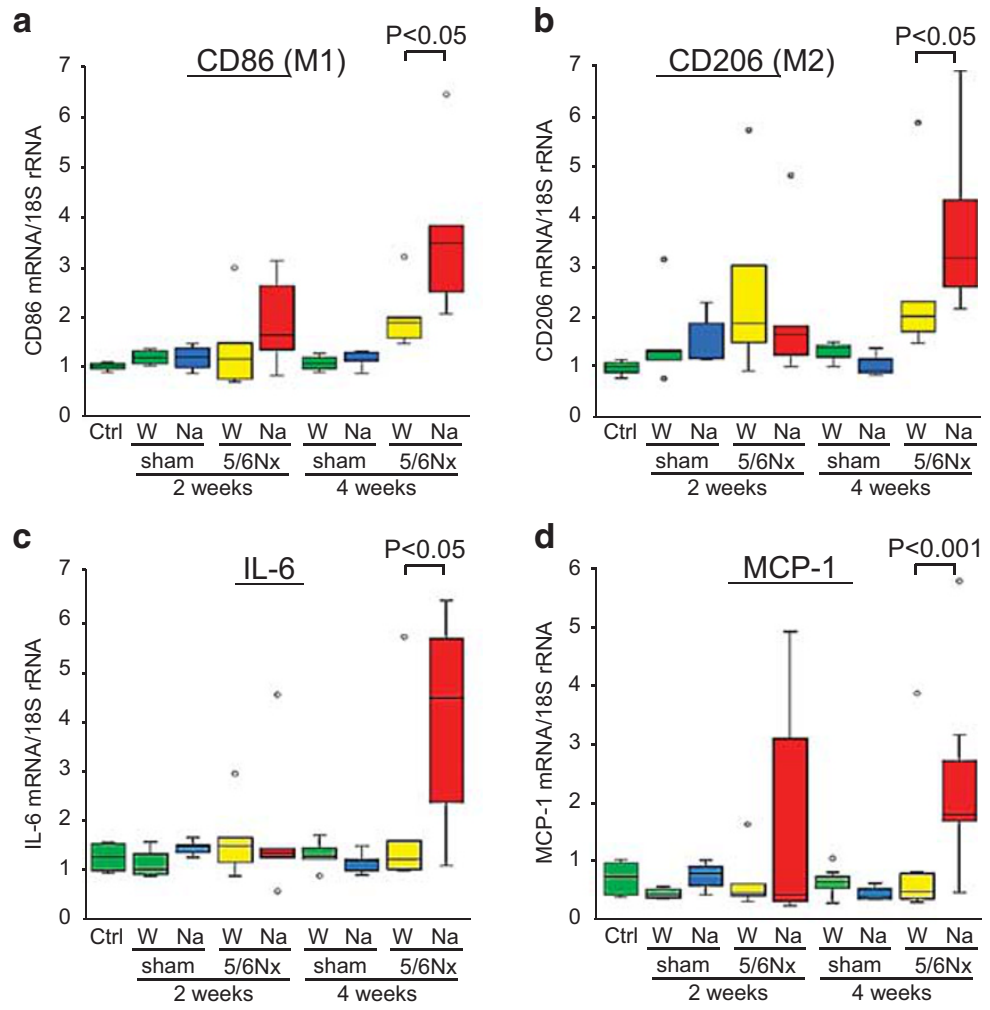

Heart
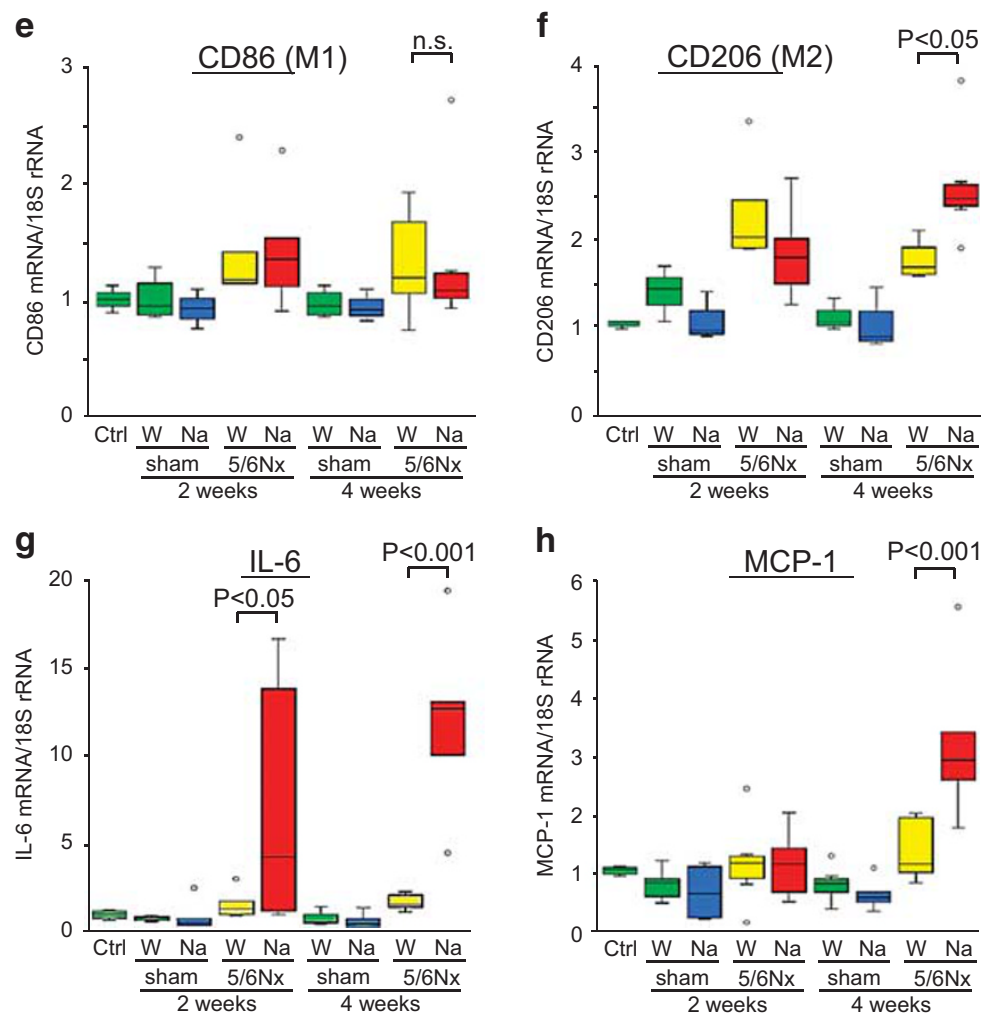

Figure 2 For caption see page 435. 
a

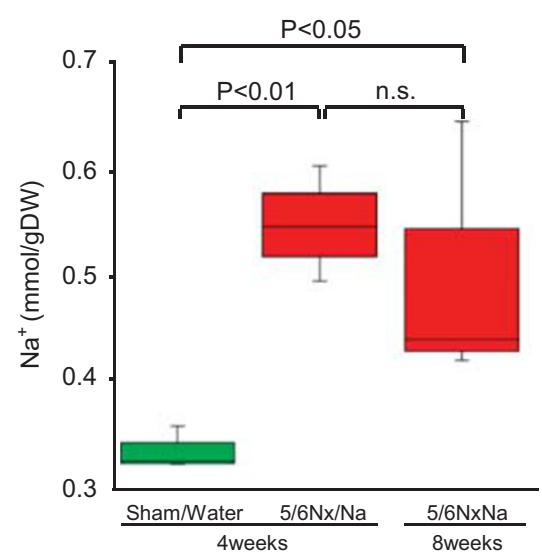

b

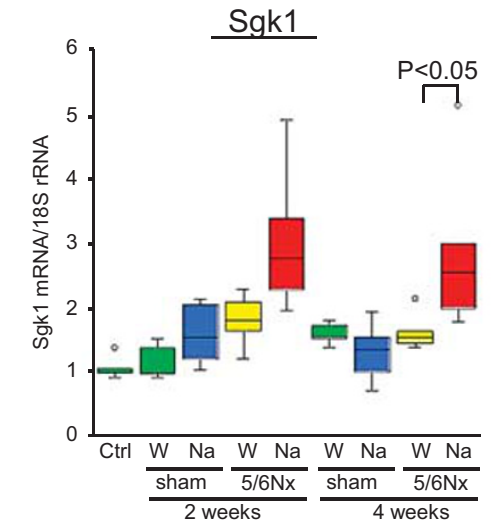

Sgk1
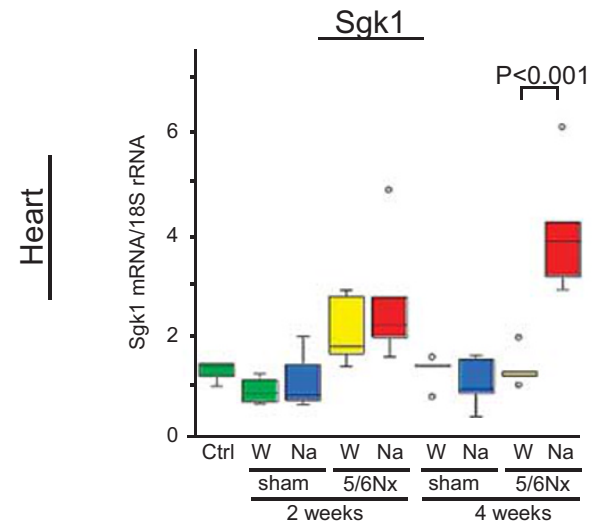

c

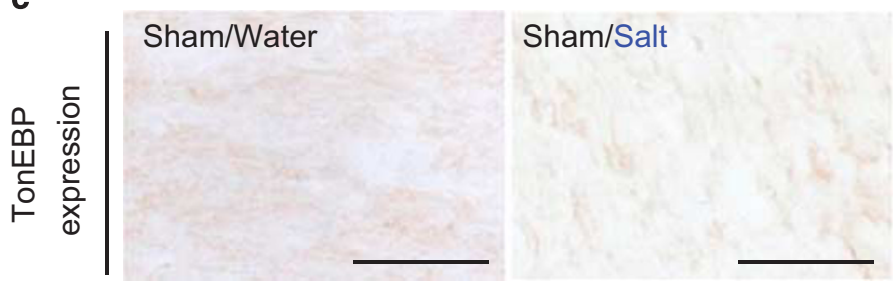

Tissue water content
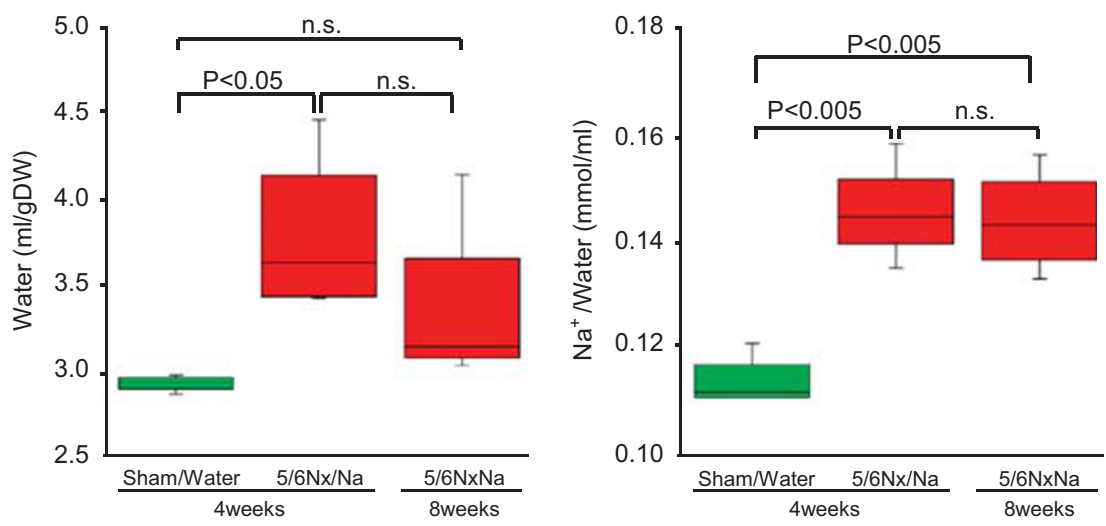

Tissue $\mathrm{Na}^{+} /$water
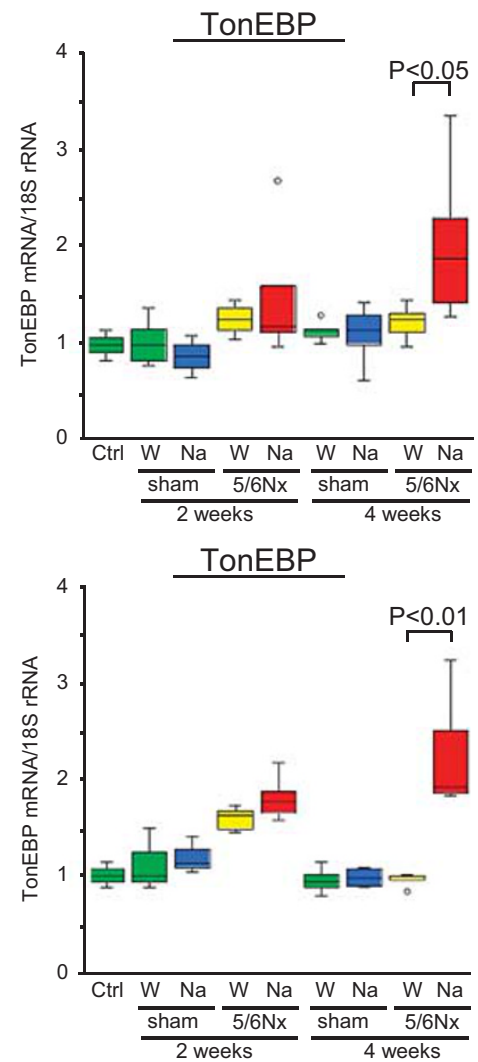

Figure 3 For caption see page 438. 


\section{RESULTS}

Increased Blood Pressure and Serum Creatinine Levels did not Differ Between Subtotal Nephrectomy with and without Salt Loading at 4 Weeks

Mice were divided into four groups in order to assess the effects of salt loading on renal failure. Mice underwent subtotal nephrectomy $(5 / 6 \mathrm{Nx})$ or sham surgery (Sham), and drinking water was either tap water (Water) or $1 \% \mathrm{NaCl}$ water $(\mathrm{NaCl})$ (Supplementary Figure 1 ). Serum creatinine and systolic blood pressure levels did not increase in Sham/Water or Sham $/ \mathrm{NaCl}$ mice (Supplementary Figure 2). We found that serum creatinine and blood pressure levels increased from 2 weeks after subtotal renal ablation, as reported previously; ${ }^{17}$ however, there were no significant differences in serum creatinine concentration and systolic blood pressure between $5 / 6 \mathrm{Nx} / \mathrm{NaCl}$ and $5 / 6 \mathrm{Nx} /$ Water mice at 2 and 4 weeks (Supplementary Figure 2).

\section{Macrophage Infiltration is Significantly Higher in Peritoneal Wall, Heart and Para-Aortic Area in 5/6 Nephrectomy with $\mathrm{NaCl}$ Loading}

At 4 weeks, CD68- and ER-HR3-positive macrophages were predominant in the peritoneal wall, heart and para-aortic tissues in $5 / 6 \mathrm{Nx} / \mathrm{NaCl}$ when compared with $5 / 6 \mathrm{Nx} /$ Water (Figure 1 and Supplementary Figure 3). These changes were associated with fibrosis (Supplementary Figure 4). Analysis of the para-aortic area was only performed on macrophage infiltration because of limitations in sample size.

\section{Time Course Expression of Surface Markers of Macrophages, Inflammatory Markers and Oxidative Stress in 5/6 Nephrectomy with $\mathrm{NaCl}$ Loading} In the peritoneal wall in $5 / 6 \mathrm{Nx} / \mathrm{NaCl}$ mice, CD68-, CD86(M1), CD206- and CD163 (M2)-positive macrophages were elevated from 2 to 4 weeks; however, there were no significant differences between 2 and 4 weeks (Supplementary Figure 5). Increases in CD68, CD206 and CD163 in the hearts from $5 / 6 \mathrm{Nx} / \mathrm{NaCl}$ mice were similar to those in the peritoneal wall; in contrast, CD86 did not increase significantly (Supplementary Figure 5). T cells were rarely detectable in both tissues at 4 weeks, whereas some CD4 cells were detected in the para-aortic area (Supplementary Figure 6).

In the peritoneal wall at 4 weeks, CD86, CD206, IL-6 and MCP-1 mRNA expression was significantly higher in $5 / 6 \mathrm{Nx} /$ $\mathrm{NaCl}$ mice than in $5 / 6 \mathrm{Nx} /$ Water mice. In the heart at 4 weeks, CD206, IL-6 and MCP-1 mRNA expression was significantly higher in $5 / 6 \mathrm{Nx} / \mathrm{NaCl}$ mice than in $5 / 6 \mathrm{Nx} /$ Water mice. IL-6 mRNA was already elevated at 2 weeks, and there were no significant increases in CD86 mRNA expression at 4 weeks (Figure 2). Serum IL-6, often used as a systemic inflammatory marker in clinical settings, ${ }^{28}$ was upregulated in both the $5 / 6 \mathrm{Nx} / \mathrm{NaCl}$ and $5 / 6 \mathrm{Nx} /$ Water mice; however, we did not find any significant differences between the groups (Supplementary Figure 7).

Oxidative stress is known to be a feature of CKD, and a driver of CKD, cardiovascular progression and other complications. ${ }^{1,29-31}$ In this study, NOX-2 and -4 mRNA expression in the peritoneal wall and heart was significantly elevated at 4 weeks in $5 / 6 \mathrm{Nx} / \mathrm{NaCl}$ mice when compared with levels in $5 / 6 \mathrm{Nx} /$ Water mice (Supplementary Figure $8 \mathrm{a}$ ), thus suggesting that oxidative stress was more strongly generated under $5 / 6 \mathrm{Nx} / \mathrm{NaCl}$ conditions. However, increases in NOX-2 and -4 mRNA were not prominent in $5 / 6 \mathrm{Nx} /$ Water mice (Supplementary Figure 8a). Antioxidants, such as Gsr, Gclc and Txnrd1 in nuclear factor-like 2 (Nrf2) response pathways, were upregulated in $5 / 6 \mathrm{Nx} / \mathrm{NaCl}$ mice at 4 weeks (Supplementary Figure 8).

\section{Storage of $\mathrm{Na}$ in Abdominal Wall Tissues, Activation of Sgk1 and TonEBP were Observed after 5/6 Nephrectomy with Salt Loading}

We found that $\mathrm{Na}$ storage in the abdominal wall tissues was significantly increased in the 4 weeks $5 / 6 \mathrm{Nx} / \mathrm{NaCl}$ mice and 8 weeks $5 / 6 \mathrm{Nx} / \mathrm{NaCl}$ mice when compared with Sham/Water mice (Figure 3a). These findings are compatible with the $\mathrm{Na}$ storage in lower limbs recently reported in hemodialysis patients. ${ }^{32}$

Sgk1, a mineralocorticoid receptor-dependent gene, was upregulated at 4 weeks in $5 / 6 \mathrm{Nx} / \mathrm{NaCl}$ mice. In addition, TonEBP mRNA was elevated in $5 / 6 \mathrm{Nx} / \mathrm{NaCl}$ mice (Figure 3b). Immunohistochemistry studies showed that TonEBP translocated into the nuclei in $5 / 6 \mathrm{Nx} / \mathrm{NaCl}$ mice, whereas in other groups, only faint cytoplasmic staining was observed (Figure 3c).

\section{Reversal of Salt Loading by Furosemide or Change from High Salt to Water Administration Reduced Macrophage Infiltration Associated with Decreased MCP-1 and TonEBP Expression in 5/6 Nephrectomy with $\mathrm{NaCl}$ Loading}

In order to reverse $\mathrm{NaCl}$ loading, we administered furosemide subcutaneously to $5 / 6 \mathrm{Nx} / \mathrm{NaCl}$ mice. Systolic blood pressure, body weight and serum creatinine levels did not change between $5 / 6 \mathrm{Nx} / \mathrm{NaCl}$ mice and $5 / 6 \mathrm{Nx} / \mathrm{NaCl}$ mice with furosemide (Supplementary Figure 9). However, macrophage infiltration in the peritoneal wall $(P<0.01)$, heart $(P<0.01)$

Figure 3 TonEBP and activation of Sgk1 were enhanced at 4 weeks in peritoneal wall and heart after 5/6 nephrectomy with NaCl loading. (a) Measurement of tissue Na and water content. (b) Messenger RNA expression was assessed by real-time PCR. (c) Immunohistochemistry for TonEBP in heart. TonEBP was translocated into the nucleus in $5 / 6 \mathrm{Nx} / \mathrm{NaCl}$, whereas in other groups, weak cytoplasmic staining was observed (c). Scale bars, $50 \mu$ m. Ctrl, control mice at 0 weeks; $\mathrm{Na}, \mathrm{NaCl}$ (with $\mathrm{NaCl}$ loading); W, water (without $\mathrm{NaCl}$ loading); 5/6Nx, subtotal nephrectomy. 
a

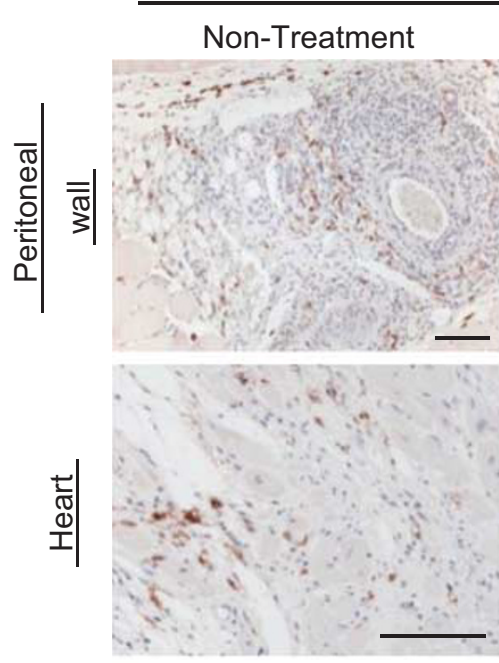

Furosemide

Non-Treatment

Furosemide

\section{b}

Peritoneal wall

Heart
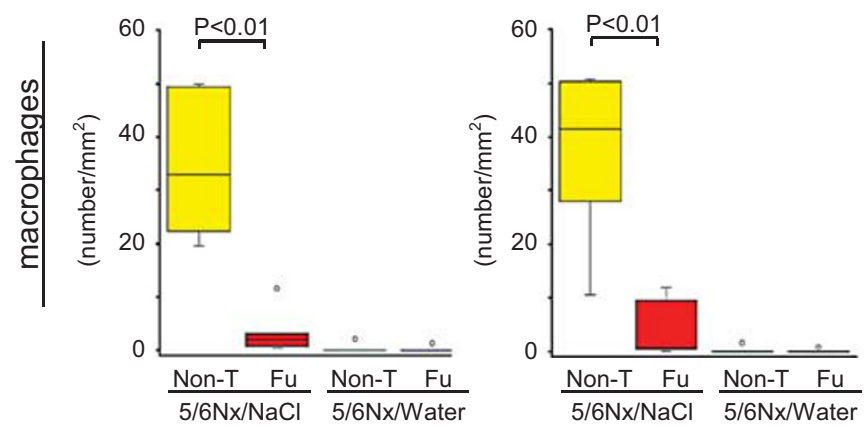

c
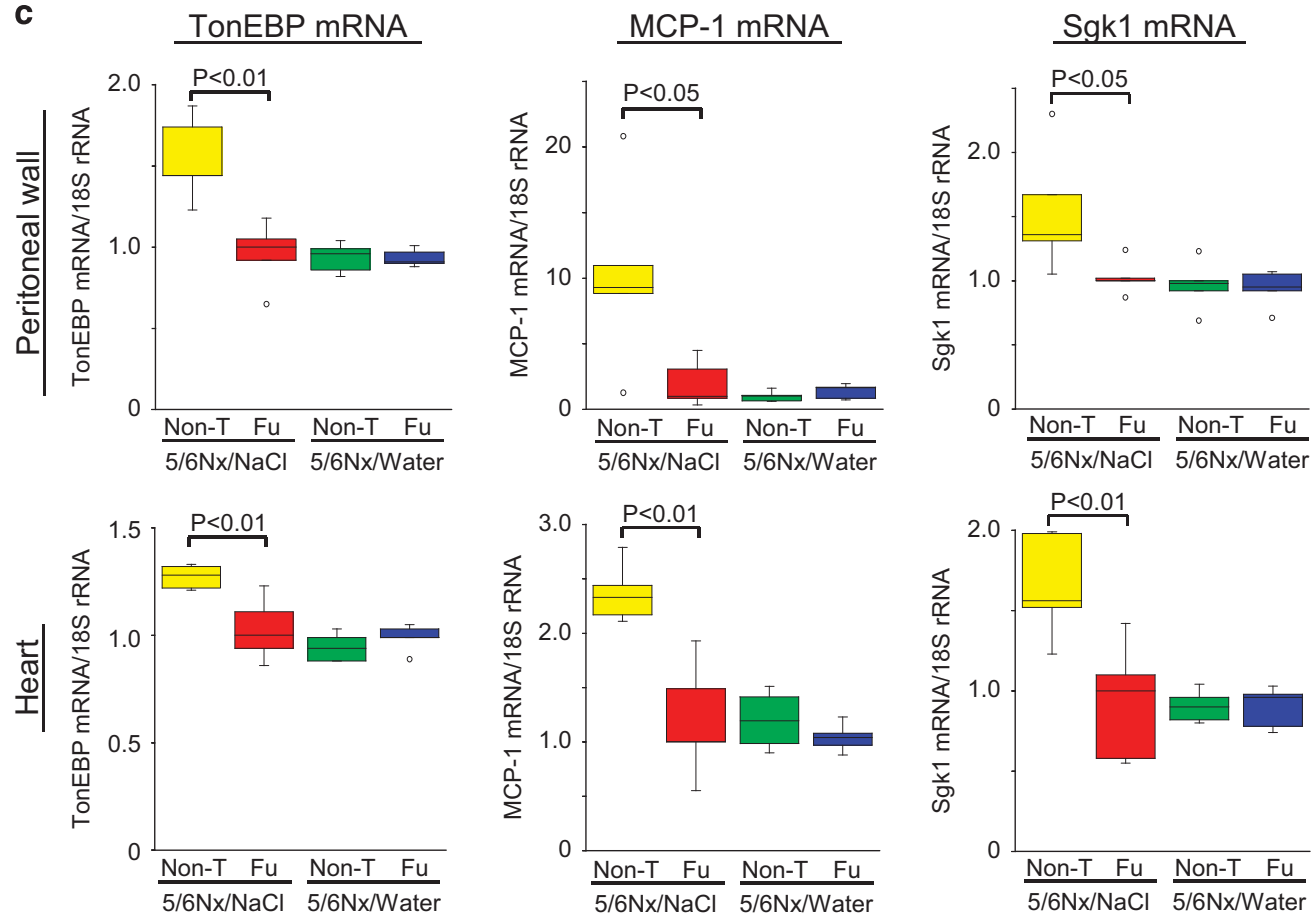

Figure 4 For caption see page 440 . 
and para-aortic area $(P<0.01)$ was significantly reduced by administration of furosemide (Figure 4,Supplementary Figure 9b). MCP-1 $(P<0.05$ for peritoneal wall and $P<0.01$ for heart), TonEBP mRNA $(P<0.01)$ and Sgk1 mRNA ( $P<0.05$ for peritoneal wall and $P<0.01$ for heart) were significantly reduced by furosemide in the peritoneal wall and in the heart (Figure 4).

In addition, changes from high salt to water administration from 4 to 8 weeks (Supplementary Figure 1c) reversed tissue macrophage infiltration associated with downregulation of TonEBP and MCP-1 mRNA expression in the peritoneal wall, heart and para-aortic area in subtotal-nephrectomized mice with salt loading (Figure 5,Supplementary Figure 10).

\section{CCR2 is Required for Macrophage Infiltration in 5/6 Nephrectomy with $\mathrm{NaCl}$ Loading}

In order to investigate the role of MCP-1, we performed inhibition studies using CCR2 (receptor of MCP-1)-deficient mice (CCR2-KO). Macrophage infiltration induced by salt loading was decreased in the $\mathrm{Nx} / \mathrm{NaCl} / \mathrm{CCR} 2-\mathrm{KO}$ mice when compared with $\mathrm{Nx} / \mathrm{NaCl} /$ Wild mice in association with reduction of fibrosis. However, there were no differences in expression of TonEBP, MCP-1 and Sgk1 mRNA between Nx/ $\mathrm{NaCl} / \mathrm{CCR} 2-\mathrm{KO}$ and $\mathrm{Nx} / \mathrm{NaCl} / \mathrm{Wild}$ mice (Figure 6, Supplementary Figure 11).

\section{Salt Enhances Tissue Macrophage Infiltration in Adenine-Induced Renal Failure Model}

In order to confirm the effects of salt loading, we studied macrophage infiltration in an adenine-induced renal failure model (Supplementary Figure 12). High-salt diet also enhanced macrophage infiltration associated with upregulation of TonEBP in the peritoneal wall and heart in adenineinduced renal failure with salt loading (Adenine $/ \mathrm{NaCl}$ ) as compared with adenine-induced renal failure without salt loading (Adenine/Water), although serum creatinine levels tended to be lower in Adenine/ $\mathrm{NaCl}$ mice (Supplementary Figure 12). There were no significant differences in blood pressure between the groups $(115.3 \pm 13.3 \mathrm{~mm} \mathrm{Hg}$ in Adenine/Water, $124.8 \pm 4.0 \mathrm{~mm} \mathrm{Hg}$ in Adenine $/ \mathrm{NaCl}$ ); these readings were lower than in the $5 / 6 \mathrm{Nx}$ model mice $(142.2 \pm 13.3 \mathrm{~mm} \mathrm{Hg}$ in $5 / 6 \mathrm{Nx} /$ Water $v s$ Adenine/Water, $P<0.01 ; 143.4 \pm 21.1 \mathrm{~mm} \mathrm{Hg}$ in $5 / 6 \mathrm{Nx} / \mathrm{NaCl}$ vs Adenine/ $\mathrm{NaCl}, P<0.05)$ (Supplementary Figures 2 and 12).

\section{NaCl-Induced Hypertonicity Increased MCP-1 in Mesothelial Cells and Cardiomyocytes through TonEBP}

We observed that MCP-1 expression was elevated in mesothelial cells and cardiomyocytes in $5 / 6 \mathrm{Nx} / \mathrm{NaCl}$ mice by immunohistochemistry (Supplementary Figure 13), and thus we focused on these cells. In mesothelial cells (Met5A) and cardiomyocytes, higher-osmotic medium containing $\mathrm{Na}$ $190 \mathrm{mEq} / \mathrm{l}$ induced upregulation of TonEBP, MCP-1 mRNA and protein, and Sgk1 mRNA; all of these were suppressed by TonEBP siRNA in a dose-dependent manner (Figure 7), indicating that both MCP-1 and Sgk1 were downstream of TonEBP. To confirm MCP-1 and Sgk1 dependency on TonEBP induction in cardiomyocytes, we suppressed TonEBP using another Accell siRNA system. Similar results were obtained at $24 \mathrm{~h}$ after incubation.

\section{RAS-Related C3 Botulinum Toxin Substrate 1 (Rac1) was not Involved in High Salt-Induced MCP-1 and Sgk1 in Mesothelial Cells and Cardiomyocytes}

We investigated whether activation of Racl was involved in the salt loading-induced upregulation of MCP-1 in $5 / 6 \mathrm{Nx} /$ $\mathrm{NaCl}$ mice. In both inhibition studies using Racl siRNA (Supplementary Figure 14) and Racl inhibitor (data not shown) in mesothelial cells and cardiomyocytes, MCP-1, TonEBP and Sgk1 were not downregulated. In addition, pulldown assay did not confirm GTP-bound-activated Rac1 following stimulation of cultured mesothelial cells with a higher-osmotic medium containing $\mathrm{Na} 190 \mathrm{mEq} / \mathrm{l}$ (Supplementary Figure 15).

\section{DISCUSSION}

Generally, loss of renal function is known to cause retention of uremic toxins and cytokines, which leads to inflammation and increased oxidative stress. ${ }^{33}$ Pro-inflammatory cytokines generate oxidative stress, whereas oxidative stress generates inflammatory immune responses resulting in further production of cytokines. ${ }^{33}$ We found that salt overload enhances macrophage infiltration associated with fibrosis in the peritoneal wall, heart and para-aortic area in subtotalnephrectomized mice when compared with 5/6Nx/Water mice (Figure 1, Supplementary Figure 4). M1 (CD86) macrophages tended to be increased only in the peritoneal wall, whereas M2 (CD163 and CD206) macrophages were elevated in the peritoneal wall and heart. These phenomena were associated with upregulation of local tissue IL-6 and MCP-1 mRNA expression, and oxidative stress. Increases in Sgk1 mRNA in the heart and peritoneal wall suggest that

Figure 4 Furosemide reduced macrophage infiltration, TonEBP, MCP-1 and Sgk1 mRNA expression in 5/6 nephrectomized mice with NaCl loading. In order to reverse $\mathrm{NaCl}$ loading, we compared $5 / 6 \mathrm{Nx} / \mathrm{NaCl}$ and $5 / 6 \mathrm{Nx} / \mathrm{NaCl}$ mice after furosemide administration (Supplementary Figure 1b). (a, b) ER-HR3positive macrophage infiltration in peritoneal wall and heart was significantly suppressed by furosemide. (c) TonEBP, MCP-1 and Sgk1 mRNA were significantly reduced by furosemide in peritoneal wall and heart. Scale bars, $100 \mu \mathrm{m}$. Fu, furosemide treatment; Non-T, non-treatment; 5/6Nx, subtotal nephrectomy. 
a
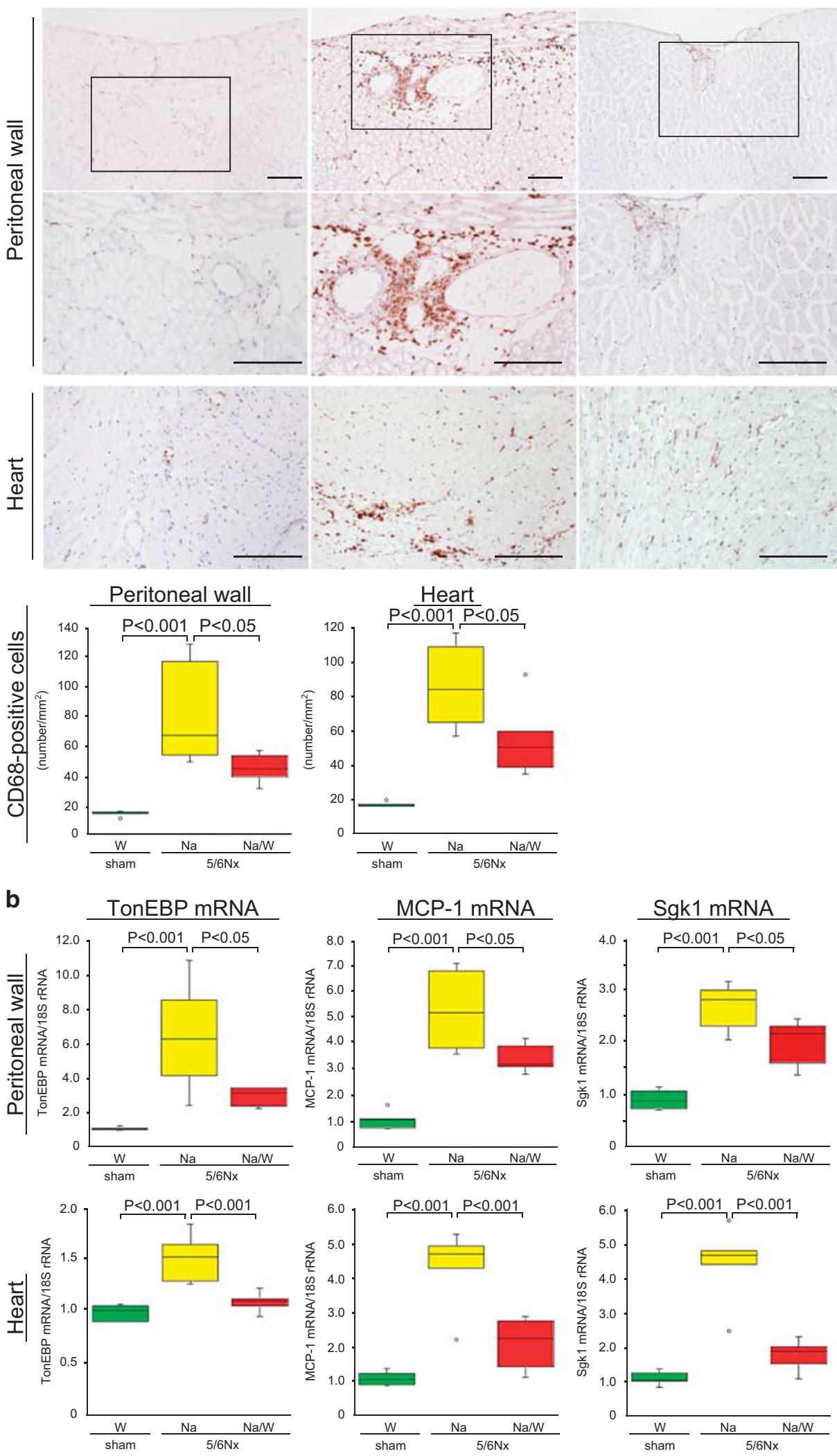

Figure 5 For caption see page 442. 
activation of mineralocorticoid receptor signaling is involved in $5 / 6 \mathrm{Nx} / \mathrm{NaCl}$ mice. We observed similar phenomena in another renal failure model. ${ }^{34}$ Tissue macrophage infiltration was enhanced in Adenine $/ \mathrm{NaCl}$ mice when compared with Adenine/Water mice; nevertheless, serum creatinine levels tended to be lower in Adenine/ $\mathrm{NaCl}$ mice (Supplementary Figure 12). The results of experiments to reverse $\mathrm{Na}$ loading by administration of furosemide or a change from salt water to tap water strengthen our theory of salt-induced tissue inflammation (Figures 4 and 5).

Local storage of $\mathrm{Na}^{+}$has been shown under disease conditions in animals and humans. ${ }^{10,13,35-38}$ After high-salt intake, electrolytes are stored in tissue, either by binding to negatively charged matrix proteoglycans or by exerting hyperosmolality. ${ }^{12,35,36}$ This uniquely bound $\mathrm{Na}^{+}$or $\mathrm{Cl}^{-}$can induce a state of local hypertonicity in the interstitium, which can induce VEGF-C production via the TonEBP activation pathway. TonEBP was initially reported to drive osmoprotective gene expression in renal medullary cells, which are routinely subjected to high extracellular osmolalities. ${ }^{39,40}$ Recent data have indicated the profound biological importance of mammalian osmotic stress response in view of TonEBP-dependent gene regulation in non-renal tissues. ${ }^{39}$ Interestingly, TonEBP is present in most tissues, including heart and skeletal muscles, ${ }^{40-42}$ and is involved in the regulation of $\mathrm{T}$ cells and $\mathrm{B}$ cells. ${ }^{40} \mathrm{NaCl}$ was also reported to drive autoimmune disease involving the TonEBP-Sgk1 signaling pathway. ${ }^{10}$ Our study suggests that in $5 / 6 \mathrm{Nx} / \mathrm{NaCl}$ mice, high $\mathrm{NaCl}$ intake induces MCP-1 expression leading to macrophage infiltration, at least in part via the TonEBPMCP-1 pathway when compared with $5 / 6 \mathrm{Nx} /$ Water mice (Figures 3, 4 and 5). This finding is supported by studies in cultured mesothelial cells and cardiomyocytes (Figure 7).

In patients with impaired kidney function, oxidative stress markers and oxidative modifications of proteins are often increased in association with inflammatory changes. ${ }^{1,29-31}$ In $5 / 6 \mathrm{Nx} / \mathrm{NaCl}$ mice, increased inflammatory mediators, such as IL-6 (Figure 2c and g,Supplementary Figure 7), are considered to contribute to increasing oxidative stress, ${ }^{43}$ which can also induce inflammation. In our experiments, salt loading enhanced oxidative stress, as well as tissue inflammation, in $5 / 6 \mathrm{Nx} / \mathrm{NaCl}$ mice. In this respect, a high-salt diet appears to lead to a vicious cycle of inflammation and oxidative stress. In addition, Sgk1, which is reported to be involved in the progression of oxidative stress, ${ }^{44}$ was found to be upregulated in $5 / 6 \mathrm{Nx} / \mathrm{NaCl}$ mice. Furthermore, we found that high tonicity-induced Sgk1 expression in cultured mesothelial cells and cardiomyocytes was regulated by TonEBP (Figure 7). This finding is consistent with previous reports regarding renal medullary cells. ${ }^{11,45}$ Racl was reported to activate Sgk1 and have an important role in renal injury in salt-sensitive hypertensive rats under salt loading; ${ }^{46,47}$ however, Racl was not involved in local macrophage infiltration in our models (Supplementary Figures 14 and 15).

In contrast to reactive oxygen species (ROS), natural antioxidant defense systems consisting of ROS scavenger molecules, such as Gsr, Gclc and Txnrd1 of the Nrf2 pathway, were activated in $5 / 6 \mathrm{Nx} \mathrm{NaCl}$ mice at 4 weeks (Supplementary Figure 8). At 12 weeks in 5/6 nephrectomized rats, Nrf2 was reportedly reduced in the kidney, but was not significantly reduced at 8 weeks. ${ }^{48}$ These data suggest that in the early stages of renal failure, intrinsic antioxidant pathways are activated to reduce oxidative stress, whereas in advanced stages, these antioxidant pathways will be suppressed.

There are few reports regarding the relationship between systemic serum inflammatory markers and local tissue inflammation in renal failure. Interestingly, higher circulating levels of the pro-inflammatory cytokine IL-6 were observed, but we were unable to discriminate the inflammatory state of the tissues between $5 / 6 \mathrm{Nx} /$ Water and $5 / 6 \mathrm{Nx} / \mathrm{NaCl}$ mice by serum IL-6 (Supplementary Figure 7). Future studies may be necessary in order to identify markers that reflect tissue inflammation.

Generally, high-salt intake is associated with increases in blood pressure in patients with chronic renal failure. Blood pressure in $5 / 6 \mathrm{Nx} / \mathrm{NaCl}$ mice was not significantly different from that in $5 / 6 \mathrm{Nx} /$ water mice at 4 weeks (Supplementary Figure 2), but was significantly higher than in $5 / 6 \mathrm{Nx} /$ water mice at 8 weeks (data not shown). Blood pressure was also not significantly different between Adenine $/ \mathrm{NaCl}$ and Adenine/Water mice at 4, 6 and 8 weeks (Supplementary Figure 12b). To rule out the effects of hypertension and to investigate the mechanisms of initial inflammatory changes, we focused on the early stages in these models; however, blood pressure tended to be higher, but not significantly so, under salt loading (Supplementary Figures 2 and 12b). In these respects, macrophage infiltration and inflammatory changes in the heart may be slightly affected by hemodynamics. There is a limitation in experiments of CCR2-KO mice. Other chemokines may be involved in macrophage tissue infiltration, as the circulating macrophage number is decreased in CCR2-KO mice. ${ }^{49,50}$

Figure 5 Removal of high-salt administration from 4 to 8 weeks reversed TonEBP and MCP-1 mRNA expression and tissue macrophage infiltration at 8 weeks in subtotal nephrectomy with salt loading. (a) CD68-positive macrophage infiltration was significantly decreased at 8 weeks, 4 weeks after the change from $1 \% \mathrm{NaCl}$ water to tap water, in both the peritoneal wall and heart of $5 / 6 \mathrm{Nx} / \mathrm{NaCl} / \mathrm{Water}$ mice. The second row shows high-magnification images of the respective boxed areas in the first row of images. (b) TonEBP, MCP-1 and Sgk1 mRNA expression in the peritoneal wall and heart of $5 / 6 \mathrm{Nx} / \mathrm{NaCl} /$ Water mice was significantly lower than in $5 / 6 \mathrm{Nx} / \mathrm{NaCl}$ mice at 8 weeks. Scale bars, $100 \mu \mathrm{m}$. $\mathrm{Na}, \mathrm{NaCl}($ with $\mathrm{NaCl}$ loading); $\mathrm{Na} / \mathrm{W}, \mathrm{NaCl} / \mathrm{Water}$ $5 / 6 \mathrm{Nx} / \mathrm{NaCl} / \mathrm{Water}$ mice were changed from $1 \% \mathrm{NaCl}$ water to water at 4 weeks; W, water (without $\mathrm{NaCl}$ loading); $5 / 6 \mathrm{Nx}$, subtotal nephrectomy. 

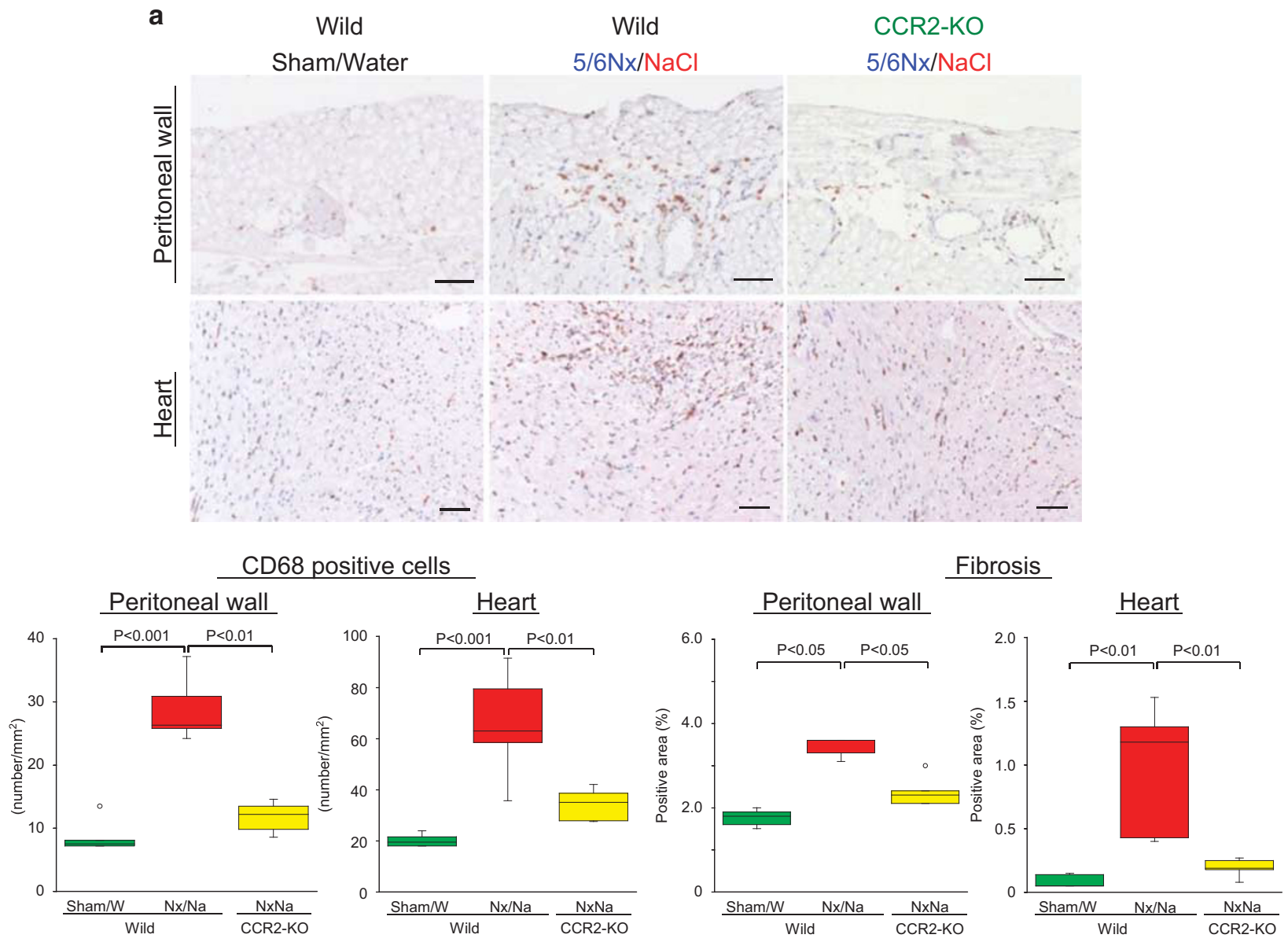

b
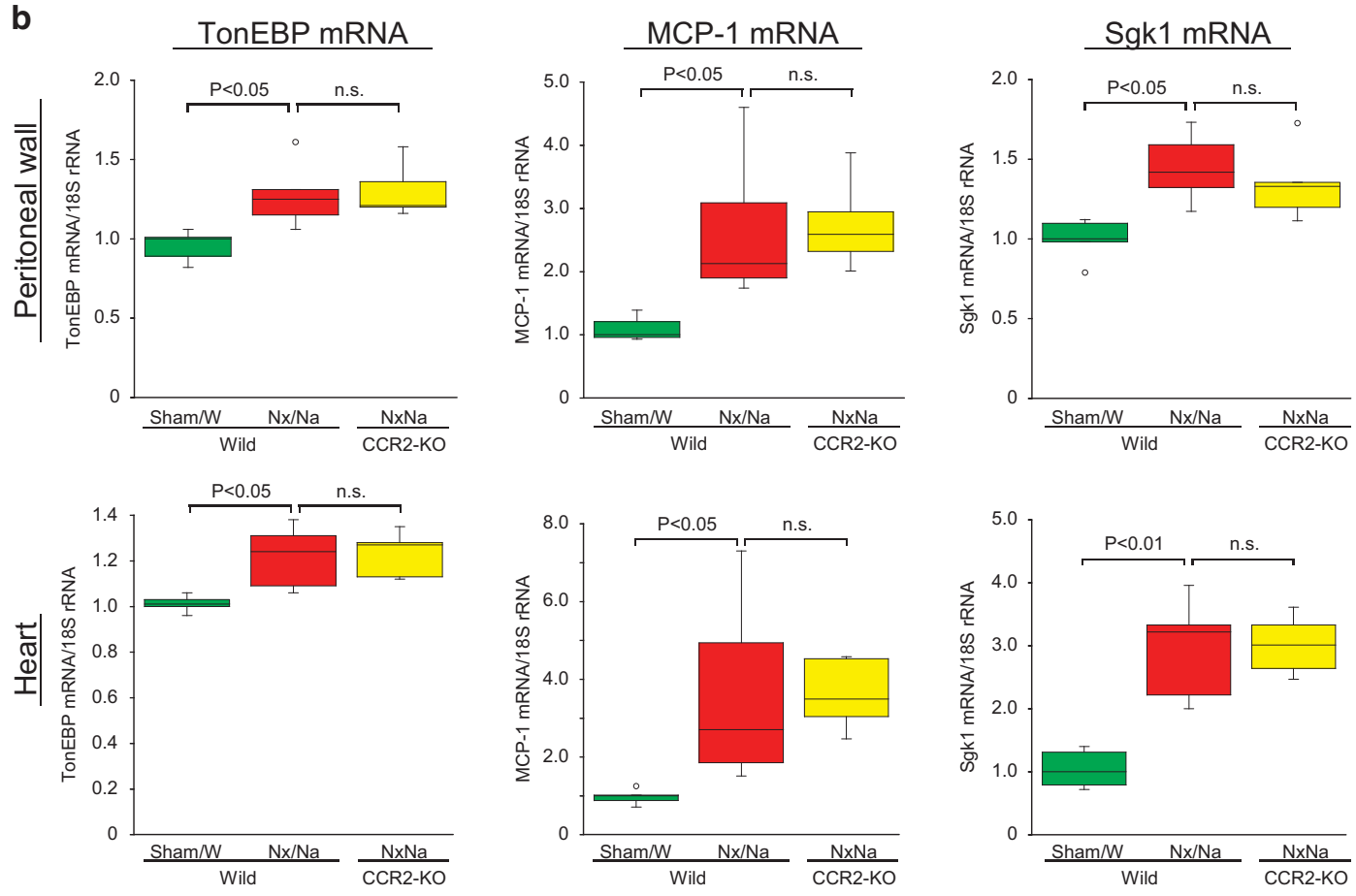

Figure 6 For caption see page 444 . 

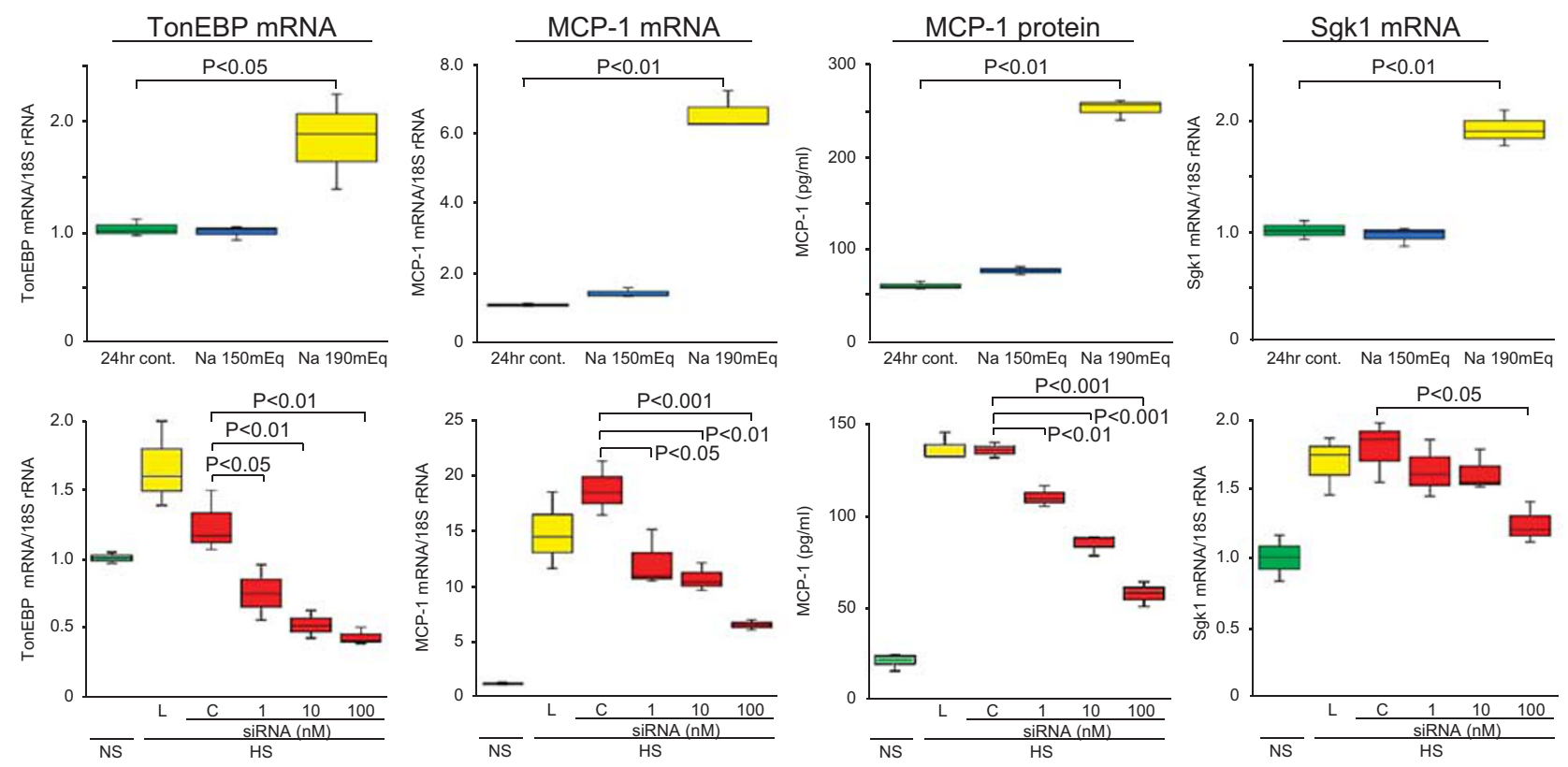

b

\section{$\mathrm{HCM}-\mathrm{NaCl}(24 \mathrm{~h})$}
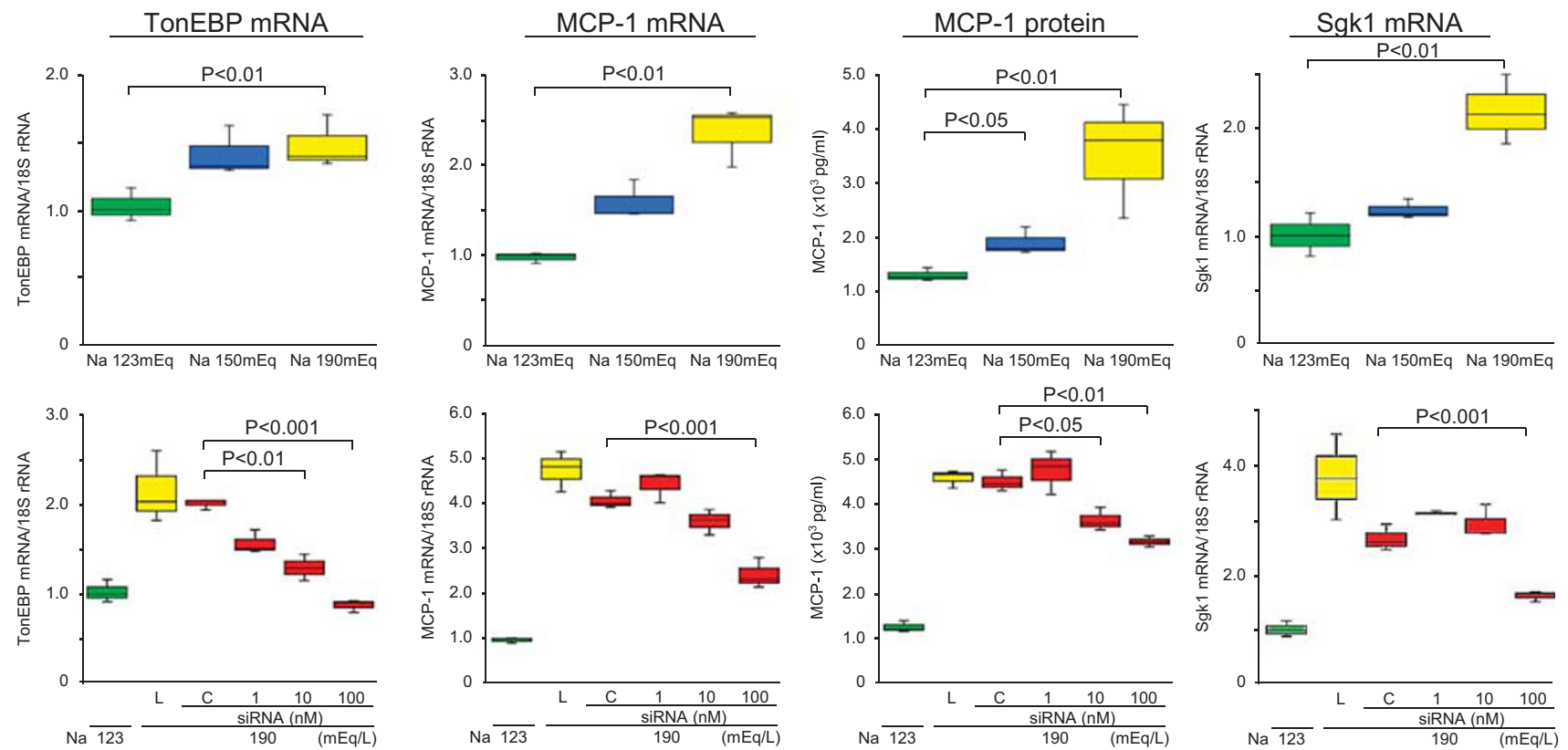

Figure 7 High tonicity with NaCl-induced MCP-1 through TonEBP in mesothelial cells and cardiomyocytes. In mesothelial cells (a, Met5A) and cardiomyocytes (b, HCM), high-osmotic medium with Na $190 \mathrm{mEq} / \mathrm{l}$ induced upregulation of MCP-1 mRNA and protein, which was suppressed by TonEBP siRNA in a dose-dependent manner. In addition, high NaCl-induced Sgk1 was also suppressed by TonEBP siRNA. TonEBP, tonicity-responsive enhancer binding protein; Sgk1, Serum- and glucocorticoid-inducible kinase 1; $24 \mathrm{~h}$ cont., basal culture medium with $\mathrm{Na} 142.5 \mathrm{mEq} / \mathrm{l}$ without supplemental $\mathrm{NaCl}$; NS, normal salt medium (Na $142.5 \mathrm{mEq} / \mathrm{l}) ; \mathrm{HS}$, high-salt medium (Na $190 \mathrm{mEq} / \mathrm{l}$ ) supplemented with $\mathrm{NaCl}$; $\mathrm{L}$, addition of only Lipofectamine RNAiMAX without siRNA; C, addition of Lipofectamine RNAiMAX with non-targeting siRNA.

Figure 6 Macrophage infiltration induced by $1 \%$ high $\mathrm{NaCl}$ loading in the peritoneal wall and heart was blocked in CCR2-deficient mice. (a) In the peritoneal wall and heart, CD68-positive macrophages were significantly decreased in the 5/6Nx/NaCl/CCR2-KO mice when compared with 5/6Nx/NaCl/Wild mice. Peritoneal fibrosis and cardiac fibrosis assessed by picrosirius red staining was upregulated in the 5/6Nx/NaCl/Wild mice; however, fibrosis was suppressed in the 5/6Nx/NaCl/CCR2-KO mice. (b) There were no differences in TonEBP, MCP-1 and Sgk1 mRNA expression in the peritoneal wall and heart between 5/6Nx/NaCl/Wild mice and 5/6Nx/NaCl/CCR2-KO mice. 
In conclusion, a high-salt diet is an important factor for inducing local macrophage infiltration via TonEBP in renal failure. We observed that this pathway is closely related to oxidative stress and mineralocorticoid receptor signaling activation. Future studies using new drugs that can directly modulate TonEBP may reduce inflammatory changes and organ damage in chronic renal failure. These strategies may be useful in dialysis patients with loss of residual renal function, in which the effects of TonEBP in medullar tubules can be ignored.

Supplementary Information accompanies the paper on the Laboratory Investigation website (http://www.laboratoryinvestigation.org)

\section{ACKNOWLEDGMENTS}

We express our gratitude to Ms Keiko Higashide, Ms Yuriko Sawa, Mr Norihiko Suzuki and Ms Naoko Asano (Department of Nephrology and Renal Replacement Therapy, Nagoya University, Nagoya, Japan) for their technical assistance. This work was supported in part by a Grant-in-Aid for Scientific Research from the Ministry of Education, Science, and Culture, Japan (YI \# $15 \mathrm{~K} 09287$ and FS \# 15K09289), the 2015 research grant from the Aichi Kidney Foundation (FS and YI).

\section{DISCLOSURE/CONFLICT OF INTEREST}

The authors declare no conflict of interest.

1. Stenvinkel P, Carrero JJ, Axelsson J, et al. Emerging biomarkers for evaluating cardiovascular risk in the chronic kidney disease patient: how do new pieces fit into the uremic puzzle? Clin J Am Soc Nephrol 2008;3:505-521.

2. Stenvinkel P. Malnutrition and chronic inflammation as risk factors for cardiovascular disease in chronic renal failure. Blood Purif 2001;19: 143-151.

3. Menon V, Greene T, Wang X, et al. C-reactive protein and albumin as predictors of all-cause and cardiovascular mortality in chronic kidney disease. Kidney Int 2005;68:766-772.

4. Friedman AN, Fadem SZ. Reassessment of albumin as a nutritional marker in kidney disease. J Am Soc Nephrol 2010;21:223-230.

5. Kalantar-Zadeh K, Kopple JD, Kilpatrick RD, et al. Association of morbid obesity and weight change over time with cardiovascular survival in hemodialysis population. Am J Kidney Dis 2005;46:489-500.

6. Takasaki K, Miyata M, Imamura M, et al. Left ventricular dysfunction assessed by cardiac time interval analysis among different geometric patterns in untreated hypertension. Circ J 2012;76:1409-1414.

7. Takahashi $H$, Ito $Y$, Ishii $H$, et al. Geriatric nutritional risk index accurately predicts cardiovascular mortality in incident hemodialysis patients. J Cardiol 2014;64:32-36.

8. Sawai $A$, Ito $Y$, Mizuno $M$, et al. Peritoneal macrophage infiltration is correlated with baseline peritoneal solute transport rate in peritoneal dialysis patients. Nephrol Dial Transplant 2011;26:2322-2332.

9. Machnik A, Neuhofer W, Jantsch J, et al. Macrophages regulate saltdependent volume and blood pressure by a vascular endothelial growth factor-C-dependent buffering mechanism. Nat Med 2009;15: 545-552.

10. Kleinewietfeld $M$, Manzel A, Titze J, et al. Sodium chloride drives autoimmune disease by the induction of pathogenic TH17 cells. Nature 2013;496:518-522.

11. Wiig H, Schröder A, Neuhofer W, et al. Immune cells control skin lymphatic electrolyte homeostasis and blood pressure. J Clin Invest 2013;123:2803-2815.

12. Marvar PJ, Gordon FJ, Harrison DG. Blood pressure control: salt gets under your skin. Nat Med 2009;15:487-488.

13. Pletinck A, Consoli C, Van Landschoot $M$, et al. Salt intake induces epithelial-to-mesenchymal transition of the peritoneal membrane in rats. Nephrol Dial Transplant 2010;25:1688-1696.

14. Kutlugün AA, Arıcı M, Yıldırım T, et al. Daily sodium intake in chronic kidney disease patients during nephrology clinic follow-up: an observational study with 24-hour urine sodium measurement. Nephron Clin Pract 2011;118:c361-c366.

15. Koomans HA, Roos JC, Dorhout Mees EJ, et al. Sodium balance in renal failure. A comparison of patients with normal subjects under extremes of sodium intake. Hypertension 1985;7:714-721.

16. Ritz E, Dikow R, Morath C, et al. Salt-a potential 'uremic toxin'? Blood Purif 2006;24:63-66.

17. Hobo A, Yuzawa $Y$, Kosugi $T$, et al. The growth factor midkine regulates the renin-angiotensin system in mice. J Clin Invest 2009;119: 1616-1625.

18. Kuziel WA, Morgan SJ, Dawson TC, et al. Severe reduction in leukocyte adhesion and monocyte extravasation in mice deficient in CC chemokine receptor 2. Proc Natl Acad Sci USA 1997;94:12053-12058.

19. Furuichi $\mathrm{K}$, Wada $\mathrm{T}$, Iwata $\mathrm{Y}$, et al. CCR2 signaling contributes to ischemia-reperfusion injury in kidney. J Am Soc Nephrol 2003;14: 2503-2515.

20. Hakroush S, Moeller MJ, Theilig F, et al. Effects of increased renal tubular vascular endothelial growth factor (VEGF) on fibrosis, cyst formation, and glomerular disease. Am J Pathol 2009;175: 1883-1895.

21. de Jong JP, Voerman JS, van der Sluijs-Gelling AJ, et al. A monoclonal antibody (ER-HR3) against murine macrophages. I. Ontogeny, distribution and enzyme histochemical characterization of ER-HR3-positive cells. Cell Tissue Res 1994;275:567-576.

22. Suzuki $Y$, Ito $Y$, Mizuno $M$, et al. Transforming growth factor- $\beta$ induces vascular endothelial growth factor-C expression leading to lymphangiogenesis in rat unilateral ureteral obstruction. Kidney Int 2012;81: 865-879.

23. Kinashi $H$, Ito $Y$, Mizuno $M$, et al. TGF- $\beta 1$ promotes lymphangiogenesis during peritoneal fibrosis. J Am Soc Nephrol 2013;24: 1627-1642.

24. Hirayama A, Kami K, Sugimoto M, et al. Quantitative metabolome profiling of colon and stomach cancer microenvironment by capillary electrophoresis time-of-flight mass spectrometry. Cancer Res 2009;69: 4918-4925.

25. Soga $T$, Ohashi $Y$, Ueno $Y$, et al. Quantitative metabolome analysis using capillary electrophoresis mass spectrometry. J Proteome Res 2003;2:488-494.

26. Nishimura $H$, Ito $Y$, Mizuno $M$, et al. Mineralocorticoid receptor blockade ameliorates peritoneal fibrosis in new rat peritonitis model. Am J Physiol Renal Physiol 2008;294:F1084-F1093.

27. Inaba S, Nagahara S, Makita N, et al. Atelocollagen-mediated systemic delivery prevents immunostimulatory adverse effects of siRNA in mammals. Mol Ther 2012;20:356-366.

28. Barreto DV, Barreto FC, Liabeuf $S$, et al. Plasma interleukin-6 is independently associated with mortality in both hemodialysis and predialysis patients with chronic kidney disease. Kidney Int 2010;77: 550-556.

29. Ruiz S, Pergola PE, Zager RA, et al. Targeting the transcription factor Nrf2 to ameliorate oxidative stress and inflammation in chronic kidney disease. Kidney Int 2013;83:1029-1041.

30. Vaziri ND. Oxidative stress in uremia: nature, mechanisms, and potential consequences. Semin Nephrol 2004;24:469-473.

31. Vaziri ND. Roles of oxidative stress and antioxidant therapy in chronic kidney disease and hypertension. Curr Opin Nephrol Hypertens 2004;13:93-99.

32. Dahlmann A, Dörfelt K, Eicher F, et al. Magnetic resonance-determined sodium removal from tissue stores in hemodialysis patients. Kidney Int 2015;87:434-441.

33. Betjes MG. Immune cell dysfunction and inflammation in end-stage renal disease. Nat Rev Nephrol 2013;9:255-265.

34. Tamura M, Aizawa R, Hori M, et al. Progressive renal dysfunction and macrophage infiltration in interstitial fibrosis in an adenine-induced tubulointerstitial nephritis mouse model. Histochem Cell Biol 2009;131: 483-490.

35. Titze J, Lang R, llies C, et al. Osmotically inactive skin $\mathrm{Na}$ + storage in rats. Am J Physiol Renal Physiol 2003;285:F1108-F1117.

36. Titze J, Shakibaei $M$, Schafflhuber $M$, et al. Glycosaminoglycan polymerization may enable osmotically inactive $\mathrm{Na}+$ storage in the skin. Am J Physiol Heart Circ Physiol 2004;287:H203-H208.

37. Titze J, Dahlmann A, Lerchl K, et al. Spooky sodium balance. Kidney Int 2014;85:759-767. 
38. Schafflhuber M, Volpi N, Dahlmann A, et al. Mobilization of osmotically inactive $\mathrm{Na}+$ by growth and by dietary salt restriction in rats. Am J Physiol Renal Physiol 2007;292:F1490-F1500.

39. Neuhofer W. Role of NFAT5 in inflammatory disorders associated with osmotic stress. Curr Genomics 2010;11:584-590.

40. Burg MB, Ferraris JD, Dmitrieva NI. Cellular response to hyperosmotic stresses. Physiol Rev 2007;87:1441-1474.

41. Miyakawa H, Woo SK, Dahl SC, et al. Tonicity-responsive enhancer binding protein, a rel-like protein that stimulates transcription in response to hypertonicity. Proc Natl Acad Sci USA 1999;96:2538-2542.

42. Kopp C, Linz P, Dahlmann A, et al. 23Na magnetic resonance imagingdetermined tissue sodium in healthy subjects and hypertensive patients. Hypertension 2013;61:635-640.

43. Gansevoort RT, Correa-Rotter R, Hemmelgarn BR, et al. Chronic kidney disease and cardiovascular risk: epidemiology, mechanisms, and prevention. Lancet 2013;382:339-352.

44. Matsui $\mathrm{H}$, Ando K, Kawarazaki $\mathrm{H}$, et al. Salt excess causes left ventricular diastolic dysfunction in rats with metabolic disorder. Hypertension 2008;52:287-294.
45. Chen S, Grigsby CL, Law CS, et al. Tonicity-dependent induction of Sgk1 expression has a potential role in dehydration-induced natriuresis in rodents. J Clin Invest 2009;119:1647-1658.

46. Kawarazaki W, Nagase M, Yoshida S, et al. Angiotensin II- and saltinduced kidney injury through Rac1-mediated mineralocorticoid receptor activation. J Am Soc Nephrol 2012;23:997-1007.

47. Shibata S, Mu S, Kawarazaki H, et al. Rac1 GTPase in rodent kidneys is essential for salt-sensitive hypertension via a mineralocorticoid receptor-dependent pathway. J Clin Invest 2011;121:3233-3243.

48. Kim HJ, Vaziri ND. Contribution of impaired Nrf2-Keap1 pathway to oxidative stress and inflammation in chronic renal failure. Am J Physiol Renal Physiol 2010;298:F662-F671.

49. Osterholzer JJ, Chen GH, Olszewski MA, et al. Chemokine receptor 2-mediated accumulation of fungicidal exudate macrophages in mice that clear cryptococcal lung infection. Am J Pathol 2011;178:198-211.

50. Lim JK, Obara CJ, Rivollier A, et al. Chemokine receptor Ccr2 is critical for monocyte accumulation and survival in West Nile virus encephalitis. J Immunol 2011;186:471-478. 